\title{
Effects of Nitrate Injection on Microbial Enhanced Oil Recovery and Oilfield Reservoir Souring
}

\author{
Marcio Luis Busi da Silva • Hugo Moreira Soares • \\ Agenor Furigo Jr. • Willibaldo Schmidell • \\ Henry Xavier Corseuil
}

Received: 23 April 2014 / Accepted: 15 August 2014

(C) Springer Science+Business Media New York 2014

\begin{abstract}
Column experiments were utilized to investigate the effects of nitrate injection on sulfate-reducing bacteria (SRB) inhibition and microbial enhanced oil recovery (MEOR). An indigenous microbial consortium collected from the produced water of a Brazilian offshore field was used as inoculum. The presence of $150 \mathrm{mg} / \mathrm{L}$ volatile fatty acids (VFA's) in the injection water contributed to a high biological electron acceptors demand and the establishment of anaerobic sulfate-reducing conditions. Continuous injection of nitrate (up to $25 \mathrm{mg} / \mathrm{L}$ ) for 90 days did not inhibit souring. Contrariwise, in nitrogen-limiting conditions, the addition of nitrate stimulated the proliferation of $\delta$-Proteobacteria (including SRB) and the associated sulfide concentration. Denitrification-specific nirK or nirS genes were not detected. A sharp decrease in water interfacial tension (from 20.8 to $14.5 \mathrm{mN} / \mathrm{m}$ ) observed concomitantly with nitrate consumption and increased oil recovery $(4.3 \% v / v)$ demonstrated the benefits of nitrate injection on MEOR. Overall, the results support the notion that the addition of nitrate, at this particular oil reservoir, can benefit MEOR by stimulating the proliferation of fortuitous biosurfactant-producing bacteria. Higher nitrate concentrations exceeding the stoichiometric volatile fatty acid (VFA) biodegradation demands and/or the use of alternative biogenic souring control strategies may be necessary to warrant effective SRB inhibition down gradient from the injection wells.
\end{abstract}

Keywords MEOR $\cdot$ Nitrate $\cdot$ Souring inhibition $\cdot$ Water interfacial tension

M. L. B. da Silva $(\square)$

EMBRAPA, BR 153 Km 110, P.O. Box 21, Concordia, SC 89000-700, Brazil

e-mail: marcio.busi@embrapa.br

H. M. Soares · A. Furigo Jr. • W. Schmidell

Federal University of Santa Catarina, Chemical Engineering, P.O. Box 476, Florianópolis, SC 88040-970, Brazil

H. M. Soares

e-mail: soares@enq.ufsc.br

H. X. Corseuil

Federal University of Santa Catarina, Sanitary and Environmental Engineering, P.O. Box 476, Florianópolis, SC 88040-970, Brazil

e-mail: henry.corseuil@ufsc.br 


\section{Introduction}

It is known that two-thirds of the total oil reserves remains in the reservoirs after conventional oil recovery operations [1-3] due to oil viscosity and low permeability as well as the high interfacial tension between hydrocarbons and aqueous phase [3, 4]. Microbial enhanced oil recovery (MEOR) has been utilized to aid conventional oil recovery $[1,3,4]$ with promising results [5-7]. In MEOR processes, biosurfactant produced by specific microorganisms decreases water interfacial tension thus enhancing residual oil emulsification and its mobilization [5, 6, 8-13]. In situ biosurfactant production by indigenous microorganisms can be stimulated by the addition of selected nutrients such as nitrate [14]. However, the success of such strategy is dependent on the presence of specific microorganisms with desired metabolic potential to produce sufficient amounts of biosurfactant in the reservoir $[5,15,16]$.

Nitrate injection has also been considered in oil fields to inhibit sulfate-reducing bacteria (SRB) and control biogenic souring [17-23]. Due to its higher oxidation potential compared to sulfate, nitrate is preferable utilized as electron acceptor which leads to a microbial community shift from sulfate to nitrate reduction [24]. Nonetheless, the effectiveness of nitrate injection to control reservoir souring has not always been demonstrated [25]. Therefore, laboratory pilot studies simulating site-specific oil reservoir conditions are desirable to minimize potential detrimental consequences associated with the injection of nitrate at field scale.

There is a large number of microbes in oil reservoirs which cannot grow on nutritious culture media and laboratory conditions [26]. In this regard, recent incorporation of molecular methods has allowed a much better understanding of the dominant microbial composition, abundance, and dynamics in oil field reservoir [27]. For instance, microbial-mediated souring effects can be monitored by targeting specific region of the bacterial genomic 16S ribosomal RNA (rRNA) which is complimentary to many iron- and sulfate-reducing genera within the $\delta$-Proteobacteria, including Geobacter, Pelobacter (including fermentative species), Desulfovibrio, Desulfomicrobium, Desulfuromusa, and Desulfuromonas (including dissimilatory S reducers) [28]. The injection of nitrate to either enhance MEOR or inhibit souring may cause changes in microbial community structure and the proliferation of denitrifying bacteria population [24]. Two genes have been utilized to target the phylogenetically diverse denitrifying bacteria. The nirS which is more widely distributed and the nirK is found in only $30 \%$ of the denitrifiers studied so far [29]. Both genes encode for nitrite reductase, responsible for the reduction of nitrite to NO: one product contains cytochrome cd1 (the nirS) and the other contains copper (the nirK). Overall, the information provided by molecular biology tools help oil companies to employ more directed, cost-effective strategies to prevent problems associated with souring, as well as to promote MEOR [27].

The aim of this study was to investigate the effects of nitrate injection on both MEOR and souring inhibition in laboratory scale up-flow mode columns simulating site-specific conditions down gradient from the injection wells.

\section{Material and Methods}

\section{Column Experiment}

Three stainless steel columns (200-cm length and 5-cm diameter) were utilized to evaluate the effects of nitrate injection on the enhancement of microbial-mediated oil recovery and souring inhibition. These columns were equipped with eight lateral sampling ports located at 2.5, 7.5, $14,20,40,70,100$, and $150 \mathrm{~cm}$ from the column's inlet fitted with Mininert valves (SigmaAldrich). To simulate temperature conditions encountered in the $100-\mathrm{m}$ radius from the 
injection well at this particular reservoir site, columns were maintained at $40{ }^{\circ} \mathrm{C}$ by recirculating water from warm water bath through the columns' water jackets. All tubings and fittings were made of Teflon to minimize sorption and/or volatilization. Columns were packed with non-contaminated and oven-heated $\left(400^{\circ} \mathrm{C}\right)$ sterile sandy soil (granulometry of 150 and $400 \mu \mathrm{m} ; 15: 85 v / v)$. Prior to crude oil addition, the columns were continuously fed with synthetic seawater in an up-flow mode at a flow rate of $0.23 \mathrm{~mL} / \mathrm{min}$ using a highpressure liquid chromatography pump (Agilent Technologies 1200 Series). The synthetic seawater medium contained per liter destilled water $(\mathrm{g} / \mathrm{L}): \mathrm{KH}_{2} \mathrm{PO}_{4}(0.088), \mathrm{Na}_{2} \mathrm{SO}_{4}(4.4)$, $\mathrm{NaCl}$ (24.9), $\mathrm{MgCl}_{2} .6 \mathrm{H}_{2} \mathrm{O}$ (9.8), $\mathrm{KCl}(0.82), \mathrm{CaCl}_{2} .2 \mathrm{H}_{2} \mathrm{O}$ (1.59), $\mathrm{NaHCO}_{3}(0.19), \mathrm{KBr}(0.08)$, $\mathrm{Kl}(0.01), \mathrm{B}_{2} \mathrm{O}_{3}(0.04), \mathrm{FeSO}_{4} \cdot 7 \mathrm{H}_{2} \mathrm{O}(0.02), \mathrm{SrCl}_{2} \cdot 6 \mathrm{H}_{2} \mathrm{O}(0.03)$ and $1 \mathrm{~mL}$ trace element solution (mg/L): $\mathrm{CuSO}_{4} .5 \mathrm{H}_{2} \mathrm{O}(5), \mathrm{H}_{3} \mathrm{BO}_{3}$ (10), $\mathrm{MnSO}_{4} .5 \mathrm{H}_{2} \mathrm{O}$ (10), $\mathrm{ZnSO}_{4} \cdot 7 \mathrm{H}_{2} \mathrm{O}$ (70), $\mathrm{MoO}_{3}(10)$. A schematic representation of the columns experimental set up is shown in Fig. 1.

Column's hydraulic measurements were required for comparison purposes and to check for preferential flow paths. Hydraulic parameters were obtained by bromide $(1 \mathrm{~g} / \mathrm{L})$ tracer studies and data fitting to the one-dimensional (1-D) advection-dispersion equation [30]. The obtained hydraulic parameters are shown in Table 1 . The obtained pore interstitial velocity values were within typical water-flooded oil reservoirs pore velocities $(36-360 \mathrm{~cm} /$ day $)$ [31, 32]. Approximately 3 days were required to displace one pore volume.

Crude oil was slowly added to each column in an up-flow mode through the application of negative pressure ( $-27 \mathrm{psi})$ into the columns' effluent port. Water in the columns was displaced and residual oil saturation was established with the addition of $880 \mathrm{~mL}$ crude oil (columns' void volume of $1 \mathrm{~L}$ ).

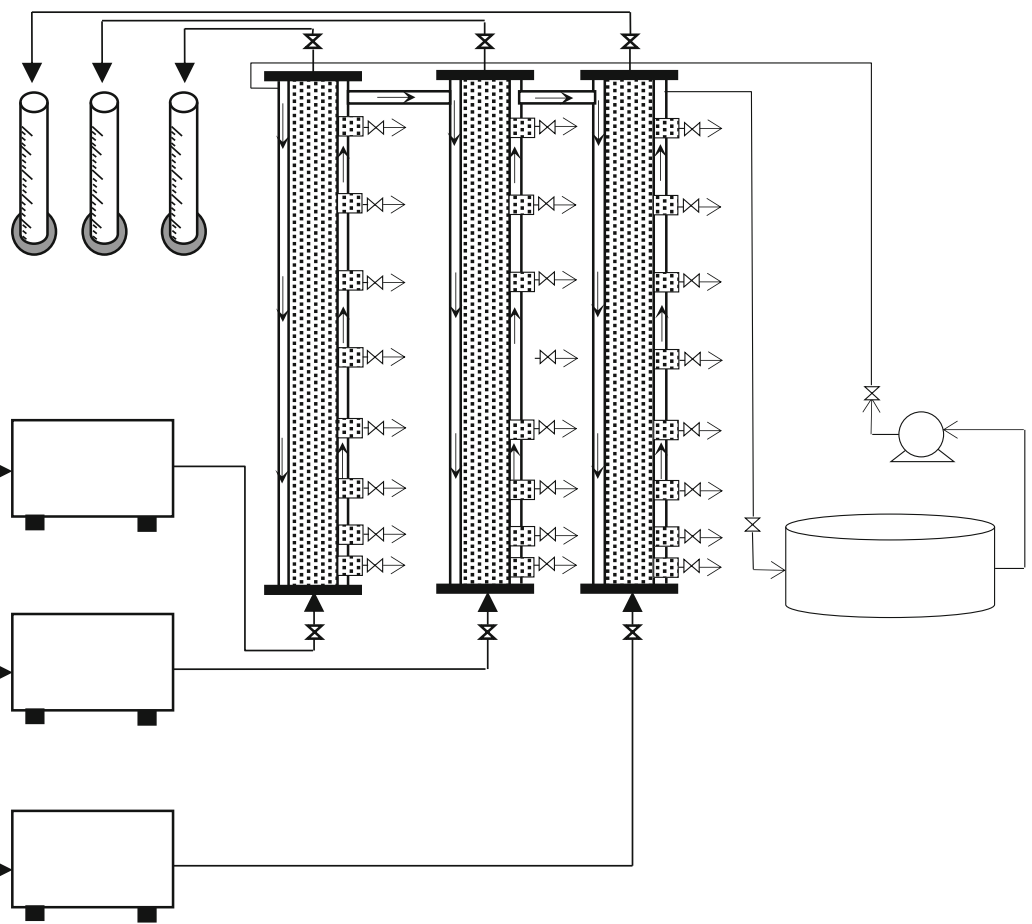

Fig. 1 Schematic representation of the columns experimental set up 
Table 1 Column's hydraulic parameters obtained by tracer data fitting to the one-dimensional (1-D) advectiondispersion equation [30]

\begin{tabular}{llll}
\hline Column & $\begin{array}{l}\text { Effective porosity } \\
(\eta \mathrm{e})\end{array}$ & $\begin{array}{l}\text { Dispersion } \\
\left(\mathrm{cm}^{2} / \mathrm{h}\right)\end{array}$ & $\begin{array}{l}\text { Pore interstitial } \\
\text { velocity }(\mathrm{cm} / \text { day })\end{array}$ \\
\hline Inoculated not fed nitrate & 0.26 & 40 & 196.8 \\
Inoculated fed nitrate & 0.25 & 30 & 206.4 \\
Non-inoculated control & 0.23 & 47 & 223.2 \\
\hline
\end{tabular}

At the end of the experiments, the residual oil remaining in the non-inoculated control column was washed out by injecting $300 \mathrm{~mL}$ of solvent hexane directly into the columns' inlet. Recovery of $884.4 \mathrm{~mL}$ from the total amount of oil added with $880 \mathrm{~mL}$ indicated that losses by volatilization or analytical error $( \pm 0.5 \%)$ were negligible.

\section{Microbial Consortium}

Microbial consortium utilized in this work was obtained from the produced water of a Brazilian offshore field. The water sample was collected through sampling valve located at the wellhead (average temperature of $30^{\circ} \mathrm{C}$ ) into a sterile 20-L carboy bottle. The bottle was filled completely with an oil/water mixture (reservoir crude oil at $1 \% \mathrm{w} / \mathrm{v}$ ) and then capped and sealed to maintain anoxic conditions. The bottle was kept on ice at $4{ }^{\circ} \mathrm{C}$ during transportation to the laboratory. The enrichment was maintained in the laboratory by replacing on a daily basis $90 \%(v / v)$ of the culture medium with new sterile synthetic seawater. Argon was utilized to purge the culturing media and warrant anaerobic conditions. The microorganism's enrichment was kept at room temperature without shaking. Two liters of the enriched bacterial consortium (representing $22 \mathrm{mg}$ total suspended solids $/ \mathrm{L}$ or $3 \%$ inoculum $v / v$ ) were utilized to inoculate the columns. Two columns were inoculated. Approximately $125 \mathrm{~mL}$ of inoculum was injected directly into each of the eight sampling ports located along the column's length utilizing a sterile syringe.

\section{Microbial Enhanced Oil Recovery (MEOR)}

Negligible oil recovery was observed after 38 days of continuous water injection as indicated by the cumulative effluent oil volume reaching a plateau (Fig. 1). At this point, two columns were inoculated. Two days prior to microbial inoculation, the feeding synthetic seawater solution was supplemented with acetate $(\cong 120 \mathrm{mg} / \mathrm{L})$ and propionate $(\cong 30 \mathrm{mg} / \mathrm{L})$. The effects of nitrate on MEOR and/or souring inhibition were evaluated by injecting nitrate initially at $12 \mathrm{mg} / \mathrm{L}$ (at 38 days of continuous water injection) then at $25 \mathrm{mg} / \mathrm{L}$ after 55 days of continuous water injection. One column was not fed nitrate and served as negative control. A noninoculated column fed synthetic seawater only was utilized as baseline to distinguish physical oil displacement (EOR) from biological MEOR. Synthetic seawater used to feed the columns was continuously purged with argon to warrant anaerobic conditions.

\section{Chemical Analysis}

Samples from the influent and side ports $(1 \mathrm{~mL})$ were collected with gas-tight syringes (Hamilton). Acetate, bromide, nitrate, nitrite, and sulfate were measured by ion chromatography IC 1000 (Dionex) equipped with an ion conductivity detector and an AS14A-4-mm column [33]. Sulfide was measured using a spectrophotometer (Hach DR/2500) according to the methylene blue method 
[33]. All chemicals used for standard analysis were analytical grade with purity $\geq 99.9 \%$. Detection limit for acetate, bromide, nitrate, nitrite, sulfate, or sulfide was $0.1 \mathrm{mg} / \mathrm{L}$.

\section{Interfacial Tension Analysis}

Surface or interfacial tension analyses are the most common and straightforward techniques utilized to assess biosurfactant production [11]. In this work, interfacial tension analysis (IFT) was used to investigate potential correlation between surfactant production and MEOR. Samples were collected along the column length and filtered $(0.22 \mu \mathrm{m}$ Millipore membrane $)$ prior to tensiometry analyses (Sigma KSV 702) according to Huh and Mason method [34]. Samples were analyzed in duplicate.

\section{Microbial Analysis}

Real-time quantitative PCR (qPCR) analyses were performed to assess the effects of nitrate injection on microbial populations harboring nitrite reductase (nirS and nirK) which are key enzymes of the denitrification process [29] as well as sulfate-reducing belonging to $\delta$ Proteobacteria [28]. After 121 days of continuous water injection, bacterial DNA was extracted from 2-mL seawater samples withdrawn from the columns' sampling ports using MoBio Ultraclean kit according to the manufacturer's protocol. DNA concentration and purity was measured based on the wavelength absorbance ratio (absorbance of $260 \mathrm{~nm}$ for DNA and $280 \mathrm{~nm}$ for protein) A260/A280 using a NanoDrop spectrophotometer. A 2- $\mu \mathrm{L}$ aliquot of bacteriophage- $\lambda$ DNA (500 bp; Sigma-Aldrich) was spiked in each sample prior to DNA extraction and used as an internal standard for the determination of DNA recovery efficiency [35].

Concentration of total bacteria $16 \mathrm{~S}$ recombinant DNA (rDNA) genes was measured using the universal bacterial primers BACT1369F and PROK1492R [35]. Nitrate-reducing bacteria genes were quantified using the primers nirK1F and nirK5R as well as the nirS1F and nirS6R [29]. Sulfate-reducing bacteria (SRB) genes were quantified using the probe EUB1 with the primers $361 \mathrm{~F}$ and $685 \mathrm{R}$ capable of targeting $\delta$-Proteobacteria [complementary to many ironand sulfate-reducing genera including Geobacter, Pelobacter (including fermentative species), Desulfovibrio, Desulfomicrobium, Desulfuromusa, and Desulfuromonas (including dissimilatory S reducers)] [28]. PCR mixtures contained $1 \times$ Taqman PCR Master Mix or SYBR Green (Applied Biosystems), $500 \mathrm{nM}$ forward and reverse primers (Integrated DNA Technologies), $250 \mathrm{nM}$ of the probe (for reactions using Taqman), and sterile DNAase-free water to make up a final volume of $25 \mu \mathrm{L}$. PCR reactions were performed in a thermocycler (Eppendorf Mastercycler ep realplex) with the following temperature conditions: $50{ }^{\circ} \mathrm{C}$ for $2 \mathrm{~min}$ followed by $95^{\circ} \mathrm{C}$ for $10 \mathrm{~min}$ and 40 cycles at $95^{\circ} \mathrm{C}$ for $15 \mathrm{~s}$ and $60{ }^{\circ} \mathrm{C}$ for one min. The genomic DNA sequences of various reference strains were utilized to prepare calibration curves for the targeted genes. Pseudomonas aeruginosa for $16 \mathrm{~S}$ rDNA and nirS, Rhizobium radiobacter for nirK, and Desulfobacterium autotrophicum for EUB1. Dilutions $\left(10^{1}\right.$ to $10^{8}$ gene copies $/ \mathrm{mL}$ ) were prepared for all calibration curves, yielding $r^{2}$ values $\geq 0.99$.

The gene copy numbers in each sample were estimated based on the following equation:

$$
\frac{\text { Gene copy number }}{\mathrm{mL}}=\left(\frac{\frac{\mu \mathrm{g} D N A}{\mathrm{~mL}}}{\frac{\mathrm{bp}}{\text { genome }}}\right) \times \frac{\mathrm{bp}}{\mu \mathrm{g} \mathrm{DNA}} \times \frac{\text { gene }}{\text { genome }}
$$

This equation assumes the size of the bacterial genome base pair (bp) used as a standard in the calibration curves [36] and the approximate $9.1 \times 10^{14} \mathrm{bp} / \mu \mathrm{g}$ of DNA. Gene copy numbers 
per genome varied according to the strain used in the calibration curve [37]. The detection limit of each assay was $\geq 10^{1}$ gene copies $/ \mathrm{mL}$.

\section{Results and Discussion}

Up-flow mode column experiments simulating water injection system from an offshore oil platform in Brazil were utilized to investigate the effects of nitrate injection on MEOR and biological souring inhibition. Continuous injection of pressurized seawater flushed the
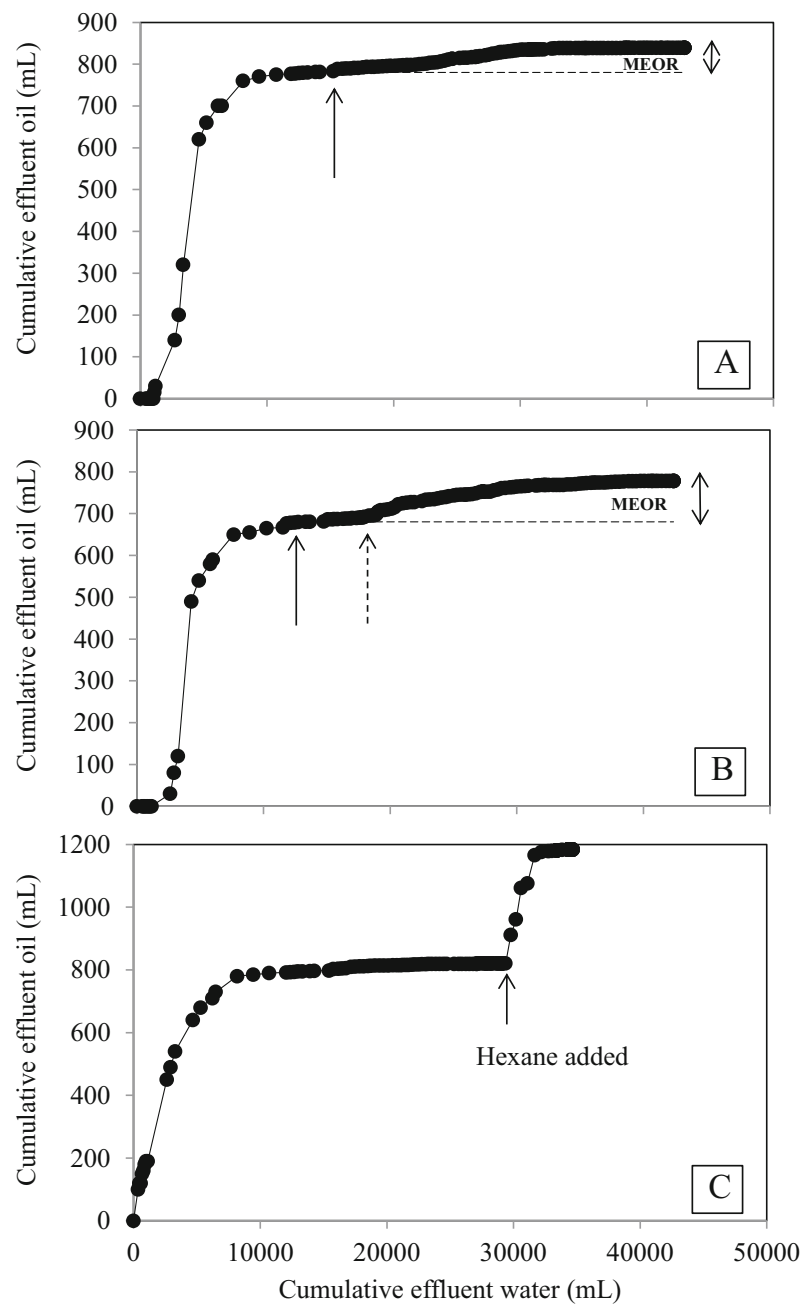

Fig. 2 Cumulative oil volumes recovered at the effluent of the inoculated column fed synthetic seawater without nitrate (a), amended nitrate (b), or non-inoculated control column (c). Water injection flow rate is $0.23 \mathrm{~mL} / \mathrm{min}$. After 38 days of continuous water injection, two columns were inoculated (solid arrow). After 55days of continuous water injection, nitrate influent concentration was increased from 12 to $25 \mathrm{mg} / \mathrm{L}$ (dashed arrow). At the end of the experiment, the remaining fraction of oil entrapped in the control column was recovered by solvent (hexane) soil washing 
sediments and displaced the entrapped oil. Prior to column inoculation, the total cumulative oil recovered by water injection (EOR) was $88 \%$ and $77 \%$ for the columns-fed synthetic seawater without and with nitrate, respectively (Fig. 2). Oil recovery in the abiotic control column was $93 \%$. These values were considerably higher than previously reported (15 to $60 \%$ ) [38] possibly due to the discrepancies in sediment materials and associated hydraulic characteristics. Nonetheless, the results served as a baseline to determine the effects of nitrate injection on MEOR.

\section{Microbial Enhanced Oil Recovery (MEOR)}

It is known that microorganisms can aid MEOR by reducing interfacial tension (IFT), altering wettability, changing preferential flow pattern, producing gas, and/or reducing oil viscosity [4, 15, 39-41]. However, recent studies have demonstrated that among these mechanisms, IFT reduction and wettability alteration are the main contributors in MEOR process [8-10, 40, 42, 43]. Relatively small reduction of IFT by up to 1 order of magnitude (or from initial 29$32 \mathrm{mN} / \mathrm{m}$ to $3.2-2.8 \mathrm{mN} / \mathrm{m}$, respectively) as result of biosurfactant production has shown to enhance oil recovery by 4 to $38.5 \% v / v[9,11]$. Significant oil recovery in these cases was attributed to biosurfactant's capacity to alter wettability which aid mobilization of the entrapped residual oil $[9,41]$.
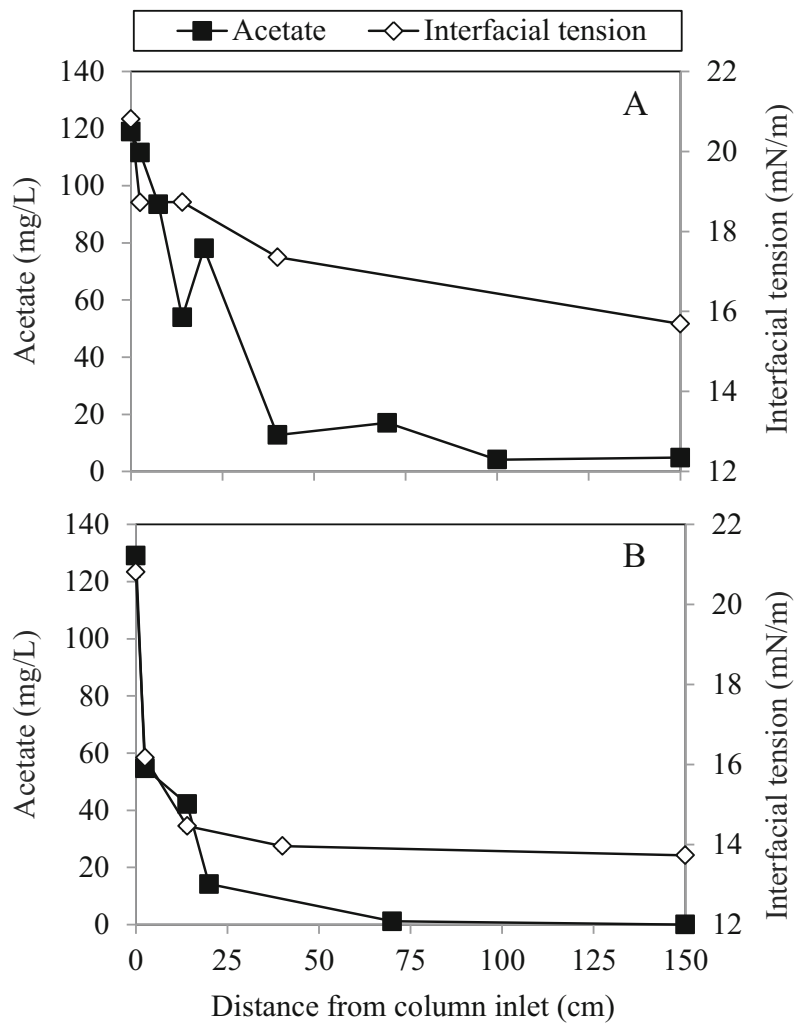

Fig. 3 Acetate and water interfacial tension concentrations profile along the inoculated columns fed synthetic seawater without nitrate (a) or amended nitrate (b). Data obtained after 121 days of continuous water injection 
In this work, a reduction of IFT served to provide circumstantial evidence to support MEOR. IFT values obtained for crude oil-brine in equilibrium $(20.8 \pm 0.07 \mathrm{mN} / \mathrm{m})$ were in agreement with previously published data $(21.2 \mathrm{mN} / \mathrm{m})$ [44]. A sharp decrease in IFT values was observed in the first $14 \mathrm{~cm}$ of the inoculated column fed nitrate (from $20.8 \pm 0.07$ to $14.4 \pm$ $0.03 \mathrm{mN} / \mathrm{m}$ ) compared to the column not fed nitrate (from $20.8 \pm 0.07$ to $18.7 \pm 0.05 \mathrm{mN} / \mathrm{m}$ (Fig. 3). The lower IFT values obtained (Fig. 3) reflected in the amount of oil recovered (Figs. 2 and 3). Oil recoveries of 6.7 and $11 \%(v / v$; normalized to EOR) were obtained for the column-fed synthetic seawater without or with nitrate, respectively (Fig. 2). It is worth noting that the rapid decrease in IFT occurred concomitantly to nitrate consumption, suggesting that nitrate played an important role as nutrient source or supplemental electron acceptor to support MEOR [45, 46].

\section{Nitrate Injection and Souring}

The biodegradation of $\cong 160 \mathrm{mg}$ volatile fatty acid (VFA) total/L present in the injection water depleted the available dissolved oxygen (approximately $184.9 \mathrm{mg} \mathrm{O}_{2} / \mathrm{L}$ would be required assuming complete acetate and propionate biodegradation to $\mathrm{CO}_{2}$ and water). The measured

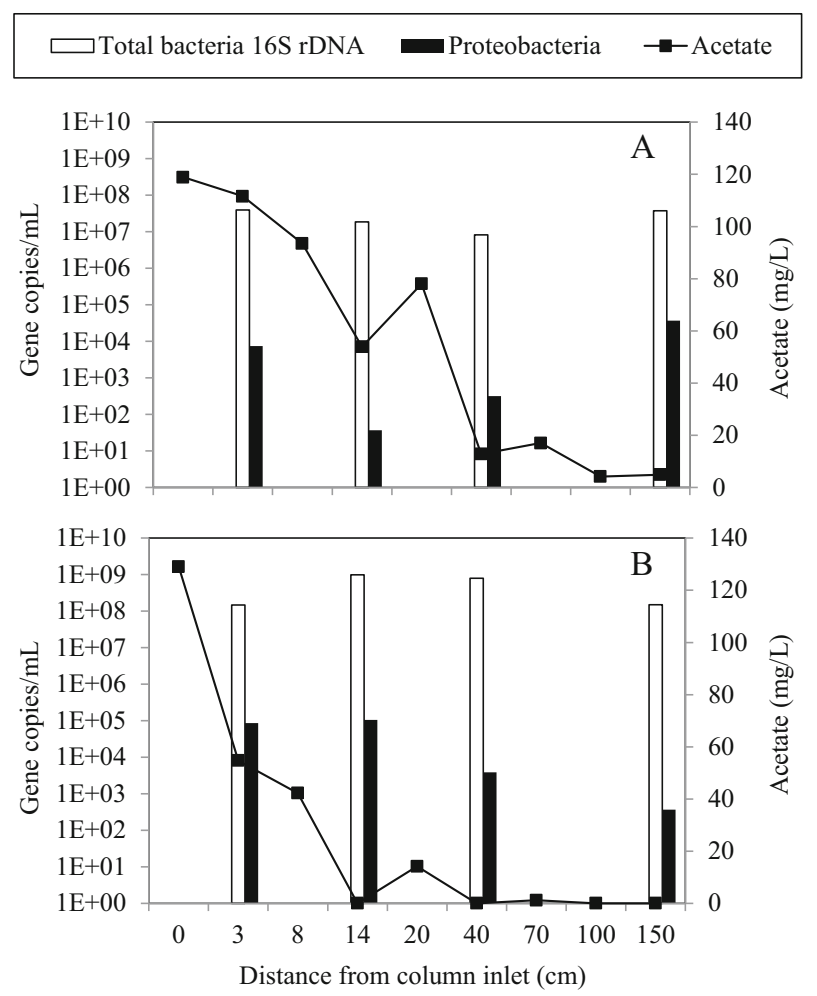

Fig. 4 Total bacteria (16S rDNA) and $\delta$-Proteobacteria [complementary to many iron- and sulfate-reducing genera including Geobacter, Pelobacter (including fermentative species), Desulfovibrio, Desulfomicrobium, Desulfuromusa, and Desulfuromonas (including dissimilatory S reducers)] concentration profiles along the inoculated columns fed synthetic seawater without nitrate (a) or amended nitrate (b). Data obtained after 121 days of continuous water injection. Nitrate-reducing bacteria were not detected (detection limit was $\geq 10^{2}$ gene copies/ $\mathrm{mL}$ ) 
oxygen concentration in the first centimeters of the column's length $(<0.1 \mathrm{mg} / \mathrm{L}$; data not shown) indicates the establishing of anaerobic conditions.

Acetate served as substrate to promote the growth of SRB (up to $10^{5}$ gene copies $/ \mathrm{mL}$ ) (Fig. 3) while SRB can also be expected to occur during the anaerobic biodegradation of hydrocarbons $[47,48]$. Although the use of nitrate and/or nitrate injection to control souring has extensively been demonstrated in laboratory [21, 23, 31, 49] and field scale [18, 50], its effectiveness has occasionally failed $[25,51]$. In this work, the continuous injection of nitrate for over 120 days neither inhibit SRB nor $\mathrm{H}_{2} \mathrm{~S}$ production irrespective to nitrate concentration tested (12 or $25 \mathrm{mg} / \mathrm{L}$ ) (Figs. 3 and 4) corroborating previous findings [52-54].

Denitrifying bacteria harboring nirS or nirK were not detected in the columns (detection limit $\geq 10^{2}$ gene copies $/ \mathrm{mL}$ ). We recognize that the primers and probes developed to target functional nirS and nirK genes are unlikely capable to encompass all natural microbial genetic diversity encountered in the oil reservoir. Consequently, limitations on the use of these functional genes may exist as a result of absence of detection and/or amplification mismatches. Nonetheless, these functional genes are useful to characterize the natural diversity of denitrifying bacteria in other marine sediments $[55,56]$.

The concentration of SRB was 1 to 4 orders of magnitude higher in the first $14 \mathrm{~cm}$ of the column fed nitrate $\left(8 \times 10^{4}\right.$ to $1 \times 10^{5}$ gene copies $\left./ \mathrm{mL}\right)$ compared to the column not fed nitrate $\left(4 \times 10^{1}\right.$ to $7 \times 10^{3}$ gene copies $\left./ \mathrm{mL}\right)$ (Fig. 4). Not surprising, sulfide production was noticeably higher near the inlet of the column fed nitrate $(8.2 \mathrm{mg} / \mathrm{L})$ compared to the column not fed

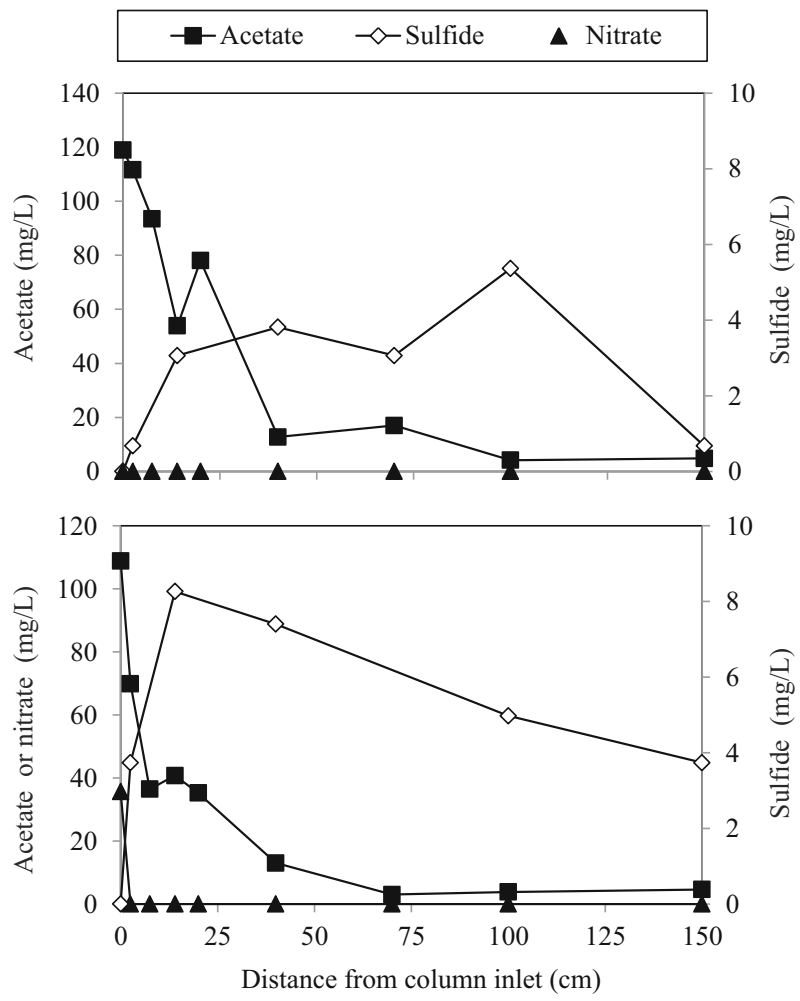

Fig. 5 Acetate, nitrate, and sulfide concentrations profile along the inoculated columns fed synthetic seawater without nitrate (a) or amended nitrate (b). Data obtained after 126 days of continuous water injection 
nitrate (3 mg/L) (Fig. 5). The higher SRB concentration near the column inlet where nitrate was rapidly being consumed indicates that in nitrogen-limited conditions, nitrate can stimulate the growth of specific SRB [53, 57-59].

The effectiveness of nitrate to suppress souring may be affected by the concentration of available VFA (acetate, propionate, butyrate, valerate) [17] in which acetate plays an important role as preferable substrate to $\mathrm{SRB}$ [60]. In this case, approximately $0.7 \mathrm{mM} \mathrm{NO} \mathrm{m}_{3}$ or $\mathrm{NO}_{2}$ : $1 \mathrm{mM}$ VFA is required to effectively inhibit souring. This stoichiometric ratio, however, may lead to too high nitrate concentrations requirements at field scale (assuming typical VFA concentrations of $100-400 \mathrm{mg} / \mathrm{L}$ and the water injection flow rates of $500-2,000 \mathrm{~m}^{3} /$ day). Moreover, it is unlikely that this correlation takes into consideration the amount of acetate produced by hydrocarbon-degrading acetogens thriving just down gradient from the injection wells where nitrate/nitrite is no longer available.

\section{Conclusions}

In this work, column experiments simulating the in situ conditions of a Brazilian offshore oil reservoir were utilized to investigate the effects of continuous nitrate injection on MEOR and reservoir souring inhibition. The implications of this work are twofold. Firstly, the continuous injection of nitrate at relatively low concentrations $(12-25 \mathrm{mg} / \mathrm{L})$ into the oil reservoir can contribute to MEOR. Secondly, in nitrogen-limiting conditions and the presence of VFA in the injection, water can adversely exert a higher nitrate demand that could be otherwise utilized to effectively inhibit SRB. In these cases, nitrate injection can stimulate the growth of specific SRB enhancing souring. Therefore, it is highly recommended to scrutinize site-specific microbial community structure and ecology information prior to implementing an effective souring control strategy based on nitrate injection.

Acknowledgments The authors thank Petrobras (Brazilian oil Company) for the financial support.

\section{References}

1. Youssef, N., Simpson, D.R., Duncan, K.E., McInerney, M.J., Folmsbee, M., Fincher, T., Knapp, R.M. (2007). Applied and Environmental Microbiology 73, 1239-124

2. Suthar, H., Hingurao, K., Desai, A., \& Nerurkar, A. (2008). Journal of Microbiological Methods, 75, 225230 .

3. Brown, L. R. (2010). Current Opinion in Microbiology, 13, 1-5.

4. Sen, R. (2008). Progress in Energy and Combustion Science, 34, 714-724.

5. Banat, I.M., Franzetti, A., Gandolfi, I., Bestetti, G., Martinotti, M.G., Fracchia, L., Smyth, T.J., Marchant, R. (2010). Applied Microbiology and Biotechnology, 87, 427-444

6. Simpson, D. R., Natraj, N. R., McInerney, M. J., \& Duncan, K. E. (2011). Applied Microbiology and Biotechnology, 91, 108-1093.

7. Thrasher, D., Puckett, D. A., Davies, A., Beattie, G., Pospisil, G., Boccardo, G., Vance, I., and Jackson, S. (2010). MEOR from lab to field, SPE129710, 17th SPE Improved Oil Recovery Symposium. Tulsa.

8. Polson, E. J., Buckman, J. O., Bowen, D. G., Todd, A. C., Gow, M. M., \& Cuthbert, S. J. (2010). SPE Journal, 15, 223-227.

9. Sarafzadeh, P., Hezave, A. Z., Ravanbakhsh, M., Niazi, A., \& Ayatollahi, S. (2013). Colloids and Surfaces B: Biointerfaces, 105, 223-229. 
10. Zargari, S., Ostvar, S., Niazi, A., \& Ayatollahi, S. (2010). Journal of Advanced Microscopy Research, 5, $143-148$

11. Rabiei, A., Sharifinik, M., Niazi, A., Hashemi, A., \& Ayatollahi, S. (2013). Applied Microbiology and Biotechnology, 97, 5979-5991.

12. Salehizadeh, H., \& Mohammadizad, S. (2009). Iranian Journal of Biotechnology, 7, 216-223.

13. Armstrong, R. T., \& Wildenschild, D. (2012). Journal of Petroleum Science and Engineering, 94-95, 155163.

14. Bhupathiraju, V. K., McInerney, M. J., \& Knapp, R. M. (1993). Geomicrobiology Journal, 11, 19-34.

15. Lazar, I., Petrisor, I. G., \& Yen, T. F. (2007). Petroleum Science and Technology, 25, 1353-1366.

16. Al-Bahry, S.N., Elshafie, A.E., Al-Wahaibi, Y.M., Al-Bemani, A.S., Joshi, S.J., Al-Maaini, R.A., Al-Alawi, W.J., Sugai, Y., Al-Mandhari, M. (2013). Journal of Microbiology and Biotechnology, 23, 106-17

17. Hubert, C., Nemati, M., Jenneman, G., \& Voordouw, G. (2003). Biotechnology Progress, 19, 338-345.

18. Bodtker, G. Thorstenson, T., Lillebo, B.L.P., Thorbjornsen, B.E., Ulvoen, R.H., Sunde, E., Torsvik, T. (2008). Journal of Industrial Microbiology and Biotechnology, 35, 1625-1636.

19. Holubnyak, Y.I., Bremer, J.M., Mibeck, B.A.F., Hamling, J.A., Huffman, B.W., Klapperich, R.J., Smith, S.A., Sorensen, J.A., \& Harju, J.A. (2011). Understanding the souring at Bakken oil reservoirs. Society of Petroleum Engineers International Symposium on Oilfield Chemistry, 11-13. The Woodlands, Texas, USA.

20. Halim, A., Watkin, E., \& Gubner, R. (2012). Eletrochimica ACTA, 77, 348-362.

21. Marques, J. M., de Almeida, F. P., Lins, U., Seldin, L., \& Korenblum, E. (2012). World Journal of Microbiology and Biotechnology, 28, 2355-2363.

22. Gieg, L. M., Jack, T. R., \& Foght, J. M. (2011). Applied Microbiology and Biotechnology, 92, $263-282$.

23. Kumaraswamy, R., Ebert, S., Gray, M. R., Fedorak, P. M., \& Foght, J. M. (2011). Applied Microbiology and Biotechnology, 89, 2027-2038.

24. Hubert, C., \& Voordouw, G. (2007). Applied and Environmental Microbiology, 73, 2644-2652.

25. Hulecki, J. C., Foght, J. M., Gray, M. R., \& Fedorak, P. M. (2009). Journal of Industrial Microbiology and Biotechnology, 36, 1499-1511.

26. van Hamme, J. D., Singh, A., \& Ward, O. P. (2003). Microbiology and Molecular Biology Reviews, 67, 503549 .

27. Whitby, C., \& Skovhus, T. L. (2011). Proceedings from the International Symposium on applied microbiology and molecular biology in oil systems (ISMOS-2), 2009. Netherlands: Springer. ISBN 978-90-4819251-9.

28. Stults, J. R., Oona-West, S., Methe, B., Lovley, D. R., \& Chandler, D. P. (2001). Applied and Environmental Microbiology, 67, 2781-2789.

29. Braker, G., Fesefeldt, A., \& Witzel, K. P. (1998). Applied and Environmental Microbiology, 64, 3769-3775.

30. Domenico, P. A., \& Schwartz, F. W. (1997). Physical and chemical hydrogeology, 2nd Edition. John Wiley \& Sons, Inc.

31. Myhr, S., Lillebo, B.-L. P., Sunde, E., Beeder, J., \& Torsvik, T. (2002). Applied Microbiology and Biotechnology, 58, 400-408.

32. Li, Y. (2011). Transport in Porous Media, 90, 333-362.

33. Standard methods for the examination of water and wastewater. (1995). American Public Health Association/ American Water Works Association/Water Environment Federation. 19th ed. Washington.

34. Huh, C., \& Mason, S. G. (1975). Colloid and Polymer Science, 253, 566-580.

35. Beller, H. R., Kane, S. R., Legler, T. C., \& Alvarez, P. J. J. (2002). Environmental Science and Technology, 36, 3977-3984.

36. Genomes online database. Available from: http://www.genomesonline.org Accessed July 22, 2014.

37. A searchable database documenting variation in ribosomal RNA operons in bacteria and archaea. Available from: http://rrndb.umms.med.umich.edu/ Accessed July 22, 2014.

38. Ollivier, B., \& Magot, M. (2005). Petroleum microbiology. Portland: ASM. Book News, Inc. 365p.

39. Afrapoli, M. S., Crescente, C., Alipour, S., \& Torsaeter, O. (2009). Journal of Petroleum Science and Engineering, 69, 255-260.

40. Crescente, C. M., Torsaeter, O., Hultmann, L., Stroem, A., Rasmussen, K., \& Kowalewski, E. (2006). An experimental study of driving mechanisms in MIOR processes by using Rhodococcus sp. 094. Paper presented at the SPE/DOE Symposium on Improved Oil Recovery, Tulsa, 22-26.

41. Karimi, M., Mahmoodi, M., Niazi, A., Al-Wahaibi, Y., \& Ayatollahi, S. (2012). Colloids and Surfaces B: Biointerfaces, 95, 129-136.

42. Ayirala, S. C., \& Rao, D. N. (2004). Colloids and Surfaces A, 24, 313-322.

43. Kowalewski, E., Rueslåtten, I., Steen, K., Bødtker, G., \& Torsaeter, O. (2006). Journal of Petroleum Science and Engineering, 52, 275-286.

44. Buckley, J. S., \& Fan, T. (2005). Crude oil/brine interfacial tensions (Vol. SCA2005-01, pp. 21-25). Canada: International Symposium of the Society of Core Analysts held in Toronto. 
45. Makkar, R. S., \& Cameotra, S. S. (1998). Journal of Industrial Microbiology and Biotechnology, 20, 48-52.

46. Okoliegbe, I. N., \& Agarry, O. O. (2012). Scholarly Journal of Biotechnology, 1, 15-23.

47. Binazadeh, M., Karimi, I. A., \& Li, Z. (2009). Enzyme and Microbial Technology, 45, 195-202.

48. She, Y.H., Zhang, F., Xia, J.J., Kong, S.Q., Wang, Z.L., Shu, F.C., Hu, J.M. (2011). Applied Biochemistry and Biotechnology, 163, 223-234.

49. Kaster, K. M., Grigoriyan, A., Jenneman, G., \& Voordouw, G. (2007). Applied and Environmental Microbiology, 75, 195-203.

50. Sunde, E., Lillebo, B.L.P., Bodtker, G., Torsvik, T., Thorstenson, T. (2004). Inhibition by nitrate injection on the Gullfaks field. Corrosion, Paper 04760, 1-14.

51. Reinsel, M. A., Sears, J. T., Stewart, P. S., \& Mclnerney, M. J. (1996). Journal of Industrial Microbiology, 17, 128-136.

52. Liu, M. C., \& Peck, H. D., Jr. (1981). Journal of Biological Chemistry, 256, 13159-13164.

53. McCready, R. G. L., Gould, W. D., \& Cook, F. D. (1983). Archives of Microbiology, 135, 182-185.

54. Odom, J. M., \& Peck, H. D., Jr. (1981). Journal of Bacteriology, 147, 161-169.

55. Braker, G., Zhou, J., Wu, L., Devol, A. H., \& Tiedje, A. J. M. (2000). Applied and Environmental Microbiology, 66, 2096-2104.

56. Braker, G., Ayala-del-Rio, H. L., Devol, A. H., Fesefeldt, A., \& Tiedje, J. M. (2001). Applied and Environmental Microbiology, 67, 1893-1901.

57. Keith, S. M., \& Herbert, R. A. (1983). FEMS Microbiology Letters, 18, 55-59.

58. Mitchell, G. J., Jones, J. G., \& Cole, J. A. (1986). Archives of Microbiology, 14, 35-40.

59. Marietou, A., Griffiths, L., \& Cole, J. (2009). Journal of Bacteriology, 191, 882-889.

60. Parkes, R. J., Gibson, G. R., Mueller-Harvey, I., Buckingham, W. J., \& Hebert, R. A. (1989). Journal of General Microbiology, 135, 175-187. 